\title{
Physiological and Yield Response of Finger Millet Grown under Different Crop Geometries and Nutrient Management Practices
}

\author{
A. Aliveni* and B. Venkateswarlu \\ Department of Agronomy, Agricultural College, Bapatla, Andhra Pradesh, India \\ *Corresponding author
}

\section{A B S T R A C T}

\begin{tabular}{|c|}
\hline Keywords \\
\hline $\begin{array}{l}\text { Yield, CGR, RGR, } \\
\text { NAR, Crop } \\
\text { geometry, Nutrient } \\
\text { management } \\
\text { practice and finger } \\
\text { millet }\end{array}$ \\
\hline Article Info \\
\hline $\begin{array}{l}\text { Accepted: } \\
07 \text { November } 2020 \\
\text { Available Online: } \\
10 \text { December } 2020\end{array}$ \\
\hline
\end{tabular}

An experiment was conducted during the kharif seasons of 2018 and 2019 at Agricultural college farm, Bapatla to study the physiological and yield performance of finger millet under different crop geometries and nutrient management practices. The trial comprised of three crop geometries with different age of seedlings $(30 \times 10 \mathrm{~cm}$ with 30 days old seedlings, $30 \times 30 \mathrm{~cm}$ with 15 days old seedlings and $45 \times 45 \mathrm{~cm}$ with 15 days old seedlings) and seven nutrient management practices $\left(\mathrm{S}_{0}\right.$ : absolute control, $\mathrm{S}_{1}$ : FYM @ 10 tons ha ${ }^{-1}+$ application of dravajeevamrutham, $\mathrm{S}_{2}$ : FYM @ 10 tons $\mathrm{ha}^{-1}+$ application of dravajeevamrutham along with wooden $\log$ treatment, $\mathrm{S}_{3}$ : FYM @ 10 tons ha ${ }^{-1}+100 \%$ RDF, $\mathrm{S}_{4}$ : FYM @ 10 tons ha ${ }^{-1}+100 \%$ RDF along with wooden log treatment, $\mathrm{S}_{5}$ : FYM @

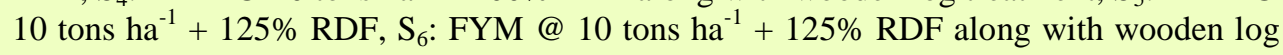
treatment) laid in split plot design and replicated thrice. The results revealed that the closer spacing of 30x10 cm, transplanted with 30 days old seedlings along with application of FYM@10 tons ha $^{-1}+125 \%$ RDF along with wooden log treatment had superiority in CGR, RGR and yield. Whereas the wider spacing of $45 \times 45 \mathrm{~cm}$ spacing transplanted with 15 days old seedlings along with absolute control had superiority in NAR.

\section{Introduction}

The agricultural productivity and availability of nutritious food at household level can be improved by identifying and improving the yield of traditional or native crops that are highly adaptive to local climate and having high nutrient value. These crops are largely consumed by indigenous communities and are often referred to as coarse cereals. Finger millet is one such crop, for addressing malnutrition and hidden hunger worldwide, grown in arid regions and adapted to adverse climatic conditions and possess superior nutritional properties. Among the different agronomic practices, crop geometry and nutrient management practices play a prominent role in improving yield levels of crops. An ideal crop geometry is essential for obtaining optimum plant stand in the field as the yield of a crop depends on the final plant density with effective utilization of growth resources.

Conjunctive use of chemical fertilizers and organic manures is important to maintain and 
sustain soil fertility and crop productivity. Organic manures enrich soil organic matter, improve soil physical and biological environment and act as store house of nutrients. Since integrated nutrient management system is gaining importance among the farmers in rainfed agro ecosystem, it is advisable to optimize the use of inorganic fertilizers along with organic manures such as FYM, for getting high yields of better quality besides keeping the production cost at sustainable level. Therefore the present experiment was conducted to study the physiological and yield performance of finger millet under different crop geometries and nutrient management practices.

\section{Materials and Methods}

Field trial was conducted to study the effect of crop geometry and nutrient management practices on physiological and yield performance of finger millet during kharif season of 2018 and 2019. The soil of experimental site was sandy clay loam in texture with slightly alkaline reaction, low organic carbon content, low available nitrogen and medium in available phosphorous and potassium. The layout of the trial was split plot design with three replications. The treatments comprised of two factors, viz., crop geometries with different age of seedlings $\left(\mathrm{M}_{1}: 30 \times 10 \mathrm{~cm}\right.$ with 30 days old seedlings, $\mathrm{M}_{2}: 30 \times 30 \mathrm{~cm}$ with 15 days old seedlings and $\mathrm{M}_{3}: 45 \times 45 \mathrm{~cm}$ with 15 days old seedlings) and seven nutrient management practices $\left(\mathrm{S}_{0}\right.$ : absolute control, $\mathrm{S}_{1}$ : FYM @ 10 tons $\mathrm{ha}^{-1}+$ application of dravajeevamrutham, $\mathrm{S}_{2}$ : FYM @ 10 tons $\mathrm{ha}^{-1}+$ application of dravajeevamrutham along with wooden log treatment, $\mathrm{S}_{3}$ : FYM @ 10 tons $\mathrm{ha}^{-1}+100 \%$ RDF, S 4 : FYM @ 10 tons ha ${ }^{-1}+100 \%$ RDF along with wooden log treatment, $\mathrm{S}_{5}$ : FYM @ 10 tons $\mathrm{ha}^{-1}+125 \%$ RDF, S 6 :FYM @ 10 tons $\mathrm{ha}^{-1}+125 \%$ RDF along with wooden $\log$ treatment). The observations on physiological parameters like CGR, RGR and NAR were recorded at 30 - 60 DAT and 60 DAT harvest intervals. Yield of finger millet was calculated based on the yield obtained from each net plot and further converted to $\mathrm{kg} \mathrm{ha}^{-1}$. To calculate CGR (Crop growth rate), RGR (Relative growth rate) and NAR (Net assimilation rate) following formula were used:

CGR $=\frac{\mathrm{w}_{2}-\mathrm{w}_{1}}{\mathrm{t}_{2}-\mathrm{t}_{1}} \times \frac{1}{\mathrm{~A}}$

Where, $\mathrm{w}_{1}=$ Total dry weight of plant $(\mathrm{g})$ at time $t_{1}, w_{2}=$ Total dry weight of plant $(\mathrm{g})$ at time $t_{2}, t_{2}-t_{1}=$ time interval (days), $A=$ Land area $\left(\mathrm{m}^{2}\right)$

$R G R=\frac{\log _{\mathrm{e}} \mathrm{w}_{2}-\log _{\mathrm{e}} \mathrm{w}_{1}}{\mathrm{t}_{2}-\mathrm{t}_{1}}$

Where, $\mathrm{w}_{1}=$ Total dry weight of plant $(\mathrm{g})$ at time $\mathrm{t}_{1}, \mathrm{w}_{2}=$ Total dry weight of plant $(\mathrm{g})$ at time $\mathrm{t}_{2}, \mathrm{t}_{2}-\mathrm{t}_{1}=$ time interval (days)

$$
\mathrm{NAR}=\frac{\mathrm{W}_{2}-\mathrm{W}_{1}}{\mathrm{t}_{2}-\mathrm{t}_{1}} \times \frac{\log _{\mathrm{e}} \mathrm{l}_{2}-\log _{\mathrm{e}} \mathrm{l}_{1}}{\mathrm{l}_{2}-\mathrm{l}_{1}}
$$

Where, $\mathrm{w}_{1}=$ Total dry weight of plant $(\mathrm{g})$ at time $\mathrm{t}_{1}, \mathrm{w}_{2}=$ Total dry weight of plant $(\mathrm{g})$ at time $t_{2}, l_{1}=$ Leaf area at time $t_{1}, l_{2}=$ Leaf area at time $\mathrm{t}_{2}, \mathrm{t}_{2}-\mathrm{t}_{1}=$ time interval days).

\section{Results and Discussion}

CGR and RGR were significantly higher at closer plant geometry of $30 \times 10 \mathrm{~cm}$ transplanted with 30 days old seedlings compared to the wider plant geometry of $45 \times 45 \mathrm{~cm}$ and $30 \times 30 \mathrm{~cm}$, transplanted with 15 days old seedlings recorded at $30-60$ DAT and 60 DAT - harvest intervals of the crop (Tables 1). RGR was not distinguishable during 30 - 60 DAT interval. The higher CGR values at closer spacing might be due to taller 
plants and more dry matter production per unit area. The results are in agreement with Nayak et al., (2003) and Oghalo (2011). Rajput et al., (2017) observed higher CGR and RGR values at closer spacing. The CGR recorded was the highest with older seedlings over younger seedlings. The present findings are in accordance with the earlier study conducted by Tilahun et al., (2013) in rice.

Table.1 CGR and RGR of finger millet as influenced by crop geometry and nutrient management practices during kharif, 2018-19 and 2019-20

\begin{tabular}{|c|c|c|c|c|c|c|c|c|c|c|c|c|}
\hline \multirow{3}{*}{$\begin{array}{r}\text { Treatments } \\
\text { Crop geometry }\end{array}$} & \multicolumn{6}{|c|}{ Crop growth rate $\left(\mathrm{g} \mathrm{m}^{-2}\right.$ day $\left.^{-1}\right)$} & \multicolumn{6}{|c|}{ Relative growth rate $\left(\mathrm{g} \mathrm{g}^{-1}\right.$ day $\left.^{-1}\right)$} \\
\hline & \multicolumn{3}{|c|}{30 - 60 DAT } & \multicolumn{3}{|c|}{ 60 DAT - HARVEST } & \multicolumn{3}{|c|}{30 - 60 DAT } & \multicolumn{3}{|c|}{60 DAT - HARVEST } \\
\hline & $\begin{array}{c}2018- \\
19\end{array}$ & $\begin{array}{c}2019- \\
20\end{array}$ & $\begin{array}{c}\text { Pooled } \\
\text { data }\end{array}$ & $\begin{array}{c}2018- \\
19\end{array}$ & $\begin{array}{c}2019- \\
20\end{array}$ & $\begin{array}{c}\text { Pooled } \\
\text { data }\end{array}$ & $\begin{array}{c}\text { 2018- } \\
19\end{array}$ & $\begin{array}{c}2019- \\
20\end{array}$ & $\begin{array}{c}\text { Pooled } \\
\text { data }\end{array}$ & $\begin{array}{c}\text { 2018- } \\
19\end{array}$ & $\begin{array}{c}2019- \\
20\end{array}$ & $\begin{array}{c}\text { Pooled } \\
\text { data }\end{array}$ \\
\hline 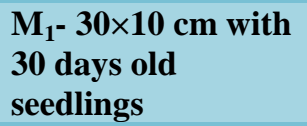 & 10.11 & 11.24 & 10.67 & 4.98 & 5.38 & 5.18 & 0.0152 & 0.0172 & 0.0162 & 0.0053 & 0.0060 & 0.0056 \\
\hline $\begin{array}{l}M_{2^{-}}-30 \times 30 \mathrm{~cm} \text { with } \\
15 \text { days old } \\
\text { seedlings }\end{array}$ & 8.87 & 10.50 & 9.68 & 3.72 & 4.00 & 3.86 & 0.0143 & 0.0183 & 0.0163 & 0.0045 & 0.0048 & 0.0047 \\
\hline $\begin{array}{l}M_{3^{-}}-45 \times 45 \mathrm{~cm} \text { with } \\
15 \text { days old } \\
\text { seedlings }\end{array}$ & 7.13 & 8.33 & 7.73 & 3.51 & 3.50 & 3.51 & 0.0145 & 0.0181 & 0.0163 & 0.0050 & 0.0051 & 0.0051 \\
\hline S.Em \pm & 0.32 & 0.31 & 0.26 & 0.11 & 0.15 & 0.09 & 0.0002 & 0.0007 & 0.0003 & 0.0001 & 0.0002 & 0.0001 \\
\hline $\mathrm{CD}(\mathrm{p}=0.05)$ & 1.25 & 1.22 & 1.00 & 0.43 & 0.60 & 0.37 & NS & NS & NS & 0.0005 & 0.0006 & 0.0005 \\
\hline CV (\%) & 16.79 & 14.24 & 12.51 & 12.41 & 16.33 & 10.35 & 7.50 & 16.70 & 7.27 & 12.39 & 13.70 & 12.11 \\
\hline \multicolumn{13}{|c|}{ Nutrient management } \\
\hline $\begin{array}{l}S_{0} \text {-Absolute } \\
\text { control }\end{array}$ & 4.61 & 5.67 & 5.14 & 1.79 & 1.68 & 1.74 & 0.0141 & 0.0193 & 0.0167 & 0.0036 & 0.0040 & 0.0038 \\
\hline $\begin{array}{l}\mathrm{S}_{1}-\mathrm{FYM} @ 10 \\
\text { tonnes ha }^{-1}+ \\
\text { dravajeevamrutham }\end{array}$ & 5.80 & 7.45 & 6.62 & 2.60 & 2.36 & 2.48 & 0.0141 & 0.0190 & 0.0166 & 0.0043 & 0.0041 & 0.0042 \\
\hline $\begin{array}{l}S_{2}-S_{1}+\text { passing } \\
\text { wooden } \log \end{array}$ & 7.89 & 9.20 & 8.54 & 3.03 & 3.48 & 3.25 & 0.0145 & 0.0182 & 0.0163 & 0.0044 & 0.0049 & 0.0046 \\
\hline $\begin{array}{l}S_{3}-\text { FYM @ } 10 \\
\text { tonnes ha-1 }+100 \% \\
\text { RDF }\end{array}$ & 9.36 & 10.73 & 10.05 & 4.62 & 4.79 & 4.70 & 0.0147 & 0.0173 & 0.0160 & 0.0054 & 0.0056 & 0.0055 \\
\hline $\begin{array}{l}\mathrm{S}_{4}-\mathrm{S}_{3}+\text { passing } \\
\text { wooden } \log \end{array}$ & 10.08 & 11.63 & 10.85 & 4.90 & 5.15 & 5.02 & 0.0147 & 0.0173 & 0.0159 & 0.0055 & 0.0059 & 0.0057 \\
\hline $\begin{array}{l}S_{5}-\text { FYM @ } 10 \\
\text { tonnes ha }{ }^{-1}+125 \% \\
\text { RDF }\end{array}$ & 11.20 & 12.65 & 11.93 & 5.69 & 6.19 & 5.94 & 0.0148 & 0.0172 & 0.0160 & 0.0056 & 0.0062 & 0.0059 \\
\hline $\begin{array}{l}S_{6}-S_{5}+\text { passing } \\
\text { wooden log }\end{array}$ & 11.99 & 12.81 & 12.40 & 5.85 & 6.44 & 6.14 & 0.0155 & 0.0170 & 0.0162 & 0.0059 & 0.0063 & 0.0061 \\
\hline S.Em \pm & 0.56 & 0.65 & 0.57 & 0.22 & 0.25 & 0.20 & 0.0005 & 0.0008 & 0.0005 & 0.0003 & 0.0004 & 0.0003 \\
\hline $\mathrm{CD}(\mathbf{p}=\mathbf{0 . 0 5})$ & 1.62 & 1.85 & 1.63 & 0.64 & 0.72 & 0.56 & NS & NS & NS & 0.0009 & 0.0010 & 0.0009 \\
\hline CV (\%) & 19.42 & 19.32 & 18.21 & 16.43 & 17.50 & 14.03 & 10.63 & 13.26 & 8.40 & 19.39 & 19.95 & 18.28 \\
\hline \multicolumn{13}{|l|}{ Interaction } \\
\hline $\mathbf{M} \times \mathbf{S}$ & NS & NS & NS & NS & NS & NS & NS & NS & NS & NS & NS & NS \\
\hline $\mathbf{S} \times \mathbf{M}$ & NS & NS & NS & NS & NS & NS & NS & NS & NS & NS & NS & NS \\
\hline
\end{tabular}


Table.2 NAR and yield of finger millet as influenced by crop geometry and nutrient management practices during kharif, 2018-19 and 2019-20

\begin{tabular}{|c|c|c|c|c|c|c|c|c|c|c|c|c|}
\hline \multirow{3}{*}{\begin{tabular}{|r|} 
Treatments \\
Crop geometry \\
\end{tabular}} & \multicolumn{6}{|c|}{ Net assimilation rate $\left(\mathrm{g} \mathrm{m}^{-2}\right.$ day $\left.^{-1}\right)$} & \multicolumn{6}{|c|}{ Yield $\left(\mathrm{kg} \mathrm{ha}^{-1}\right)$} \\
\hline & \multicolumn{3}{|c|}{ 30-60 DAT } & \multicolumn{3}{|c|}{60 DAT - HARVEST } & \multicolumn{3}{|c|}{ Grain } & \multicolumn{3}{|c|}{ Straw } \\
\hline & $\begin{array}{c}2018- \\
19\end{array}$ & $\begin{array}{l}2019- \\
20\end{array}$ & $\begin{array}{c}\text { Pooled } \\
\text { data }\end{array}$ & $\begin{array}{c}2018- \\
19\end{array}$ & $\begin{array}{l}2019- \\
20\end{array}$ & $\begin{array}{c}\text { Pooled } \\
\text { data }\end{array}$ & $\begin{array}{c}2018- \\
19\end{array}$ & $\begin{array}{l}2019- \\
20\end{array}$ & $\begin{array}{c}\text { Pooled } \\
\text { data }\end{array}$ & $\begin{array}{c}2018- \\
19\end{array}$ & $\begin{array}{c}2019- \\
20\end{array}$ & $\begin{array}{c}\text { Pooled } \\
\text { data }\end{array}$ \\
\hline 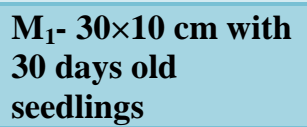 & 0.037 & 0.041 & 0.039 & 0.013 & 0.014 & 0.014 & 2668 & 2773 & 2721 & 6538 & 6722 & 6630 \\
\hline $\begin{array}{l}M_{2-}-30 \times 30 \mathrm{~cm} \text { with } \\
15 \text { days old } \\
\text { seedlings }\end{array}$ & 0.057 & 0.067 & 0.062 & 0.019 & 0.020 & 0.020 & 2258 & 2363 & 2310 & 5757 & 5896 & 5827 \\
\hline $\begin{array}{l}M_{3^{-}}-45 \times 45 \mathrm{~cm} \text { with } \\
15 \text { days old } \\
\text { seedlings }\end{array}$ & 0.071 & 0.080 & 0.075 & 0.030 & 0.029 & 0.029 & 2079 & 2172 & 2126 & 4350 & 4504 & 4427 \\
\hline S.Em \pm & 0.002 & 0.003 & 0.002 & 0.0006 & 0.0009 & 0.001 & 91.61 & 48.79 & 61.18 & 147.14 & 200.83 & 177.42 \\
\hline $\mathrm{CD}(p=0.05)$ & 0.008 & 0.010 & 0.008 & 0.003 & 0.003 & 0.002 & 360 & 192 & 240 & 578 & 789 & 697 \\
\hline CV (\%) & 17.54 & 18.28 & 16.28 & 14.27 & 18.97 & 12.81 & 17.98 & 9.18 & 11.75 & 12.15 & 16.13 & 14.45 \\
\hline \multicolumn{13}{|l|}{ Nutrient management } \\
\hline $\begin{array}{l}S_{0} \text {-Absolute } \\
\text { control }\end{array}$ & 0.067 & 0.083 & 0.075 & 0.024 & 0.023 & 0.023 & 1213 & 1324 & 1268 & 2483 & 2520 & 2502 \\
\hline $\begin{array}{l}\mathrm{S}_{1}-\mathrm{FYM} @ 10 \\
\text { tonnes ha }{ }^{-1}+ \\
\text { dravajeevamrutham }\end{array}$ & 0.069 & 0.078 & 0.074 & 0.023 & 0.024 & 0.023 & 1765 & 1837 & 1801 & 3603 & 3738 & 3671 \\
\hline $\begin{array}{l}\mathrm{S}_{2}-\mathrm{S}_{1}+\text { passing } \\
\text { wooden } \log \end{array}$ & 0.063 & 0.070 & 0.066 & 0.024 & 0.024 & 0.024 & 2051 & 2102 & 2076 & 4884 & 4944 & 4914 \\
\hline $\begin{array}{l}S_{3}-\text { FYM @ } 10 \\
\text { tonnes ha }{ }^{-1}+100 \% \\
\text { RDF }\end{array}$ & 0.053 & 0.057 & 0.055 & 0.021 & 0.022 & 0.022 & 2521 & 2668 & 2595 & 6131 & 6338 & 6234 \\
\hline $\begin{array}{l}\mathrm{S}_{4}-\mathrm{S}_{3}+\text { passing } \\
\text { wooden } \log \end{array}$ & 0.050 & 0.057 & 0.053 & 0.022 & 0.022 & 0.022 & 2761 & 2884 & 2822 & 6358 & 6737 & 6547 \\
\hline $\begin{array}{l}S_{5}-\text { FYM @ } 10 \\
\text { tonnes ha-1 }+125 \% \\
\text { RDF }\end{array}$ & 0.048 & 0.051 & 0.049 & 0.019 & 0.021 & 0.020 & 2955 & 3046 & 3000 & 7652 & 7770 & 7711 \\
\hline $\begin{array}{l}\mathrm{S}_{6}-\mathrm{S}_{5}+\text { passing } \\
\text { wooden } \log \end{array}$ & 0.037 & 0.044 & 0.041 & 0.012 & 0.013 & 0.013 & 3079 & 3191 & 3135 & 7729 & 7903 & 7816 \\
\hline S.Em \pm & 0.003 & 0.004 & 0.003 & 0.0011 & 0.0014 & 0.001 & 136.30 & 128.22 & 98.73 & 325.33 & 388.27 & 320.07 \\
\hline $\mathrm{CD}(\mathbf{p}=\mathbf{0 . 0 5})$ & 0.009 & 0.011 & 0.010 & 0.003 & 0.004 & 0.003 & 391 & 368 & 283 & 933 & 1114 & 918 \\
\hline CV (\%) & 16.55 & 17.88 & 17.21 & 16.20 & 19.70 & 14.83 & 17.51 & 15.79 & 12.42 & 17.59 & 20.41 & 17.06 \\
\hline \multicolumn{13}{|l|}{ Interaction } \\
\hline $\mathbf{M} \times \mathbf{S}$ & NS & NS & NS & NS & NS & NS & NS & NS & NS & NS & NS & NS \\
\hline S X M & NS & NS & NS & NS & NS & NS & NS & NS & NS & NS & NS & NS \\
\hline
\end{tabular}

With regard to the nutrient management practices, application of FYM @ 10 tons ha ${ }^{-1}$ $+125 \%$ RDF along with wooden log treatment recorded the higher CGR and was comparable with FYM @ 10 tons ha ${ }^{-1}+125 \%$ $\operatorname{RDF}\left(\mathrm{S}_{5}\right)$. The influence of various nutrient management treatments were significant regarding the RGR at 60 DAT-harvest interval only and higher RGR values were observed with FYM @ 10 tons ha ${ }^{-1}+125 \%$ RDF along with wooden $\log$ treatment $\left(\mathrm{S}_{6}\right)$ and was on a par with all other integrated 
nutrient management practices with and without wooden $\log$ treatment $\left(\mathrm{S}_{3}, \mathrm{~S}_{4}\right.$ and $\left.\mathrm{S}_{5}\right)$. Higher doses of nutrients resulting in higher availability of nutrients in the soil for plant nourishment and combined use of nutrients in desired quantity may be attributed to improvement in physico-chemical and biological properties of soil which maintained continuous supply of nutrient to crop which increased plant growth attributes (Singh et al., 2018).

The highest NAR was recorded with wider spacing of $45 \times 45 \mathrm{~cm}$ and planting 15 days aged seedlings $\left(\mathrm{M}_{3}\right)$, followed by $\mathrm{M}_{2}$ and $\mathrm{M}_{1}$ treatments. The NAR increased with increase in spacing. Similar results were reported by Mohabbesi et al., (2011), Sridhara et al., (2011) and Rajput (2013).

With regard to the nutrient management treatments higher NAR values were registered with absolute control compared to the other management treatments. A decrease in net assimilation rate was observed with increased levels of nutrients may be attributed to the effect of this nutrients on relative rates of photosynthesis and respiration. Increase in vegetative growth significantly with increased doses of nutrients might be expected to increase the respiration of plants markedly and have resulted in an increase in mutual shading of leaves with a resultant decrease in photosynthetic activity. The overall net photosynthesis per unit of photosynthesizing tissue thus came down. Similar results were also observed by Varghese et al., (1976) in sunflower.

The grain and straw yield were significantly higher at the closer spacing of $30 \times 10 \mathrm{~cm}$, which was significantly superior over the other two spacings and the lowest grain and straw yield were registered at the spacing of $45 \times 45 \mathrm{~cm}$ during both the years of study and in pooled data. Though wider spacing favored for most of the yield attributes compared to closer spacing, it could not compensate the yield on a unit area basis showing the superiority of closer spacing over wider spacing as number of plants per unit area are more in closer spacing which is reflected in yield $\mathrm{ha}^{-1}$. Similar findings at closer spacing was also reported by Borkar et al., (2008), Rajesh, (2011), Kalaraju et al., (2011) and Anitha (2015).

Application of FYM @ 10 tons ha ${ }^{-1}+125 \%$ $\mathrm{RDF}$ along with wooden $\log$ treatment $\left(\mathrm{S}_{6}\right)$ registered significantly higher grain and straw yield and statistically comparable with $\mathrm{S}_{5}$ treatment. The absolute control recorded significantly lower grain and straw yields during both the years of study and in pooled data.

Sustained release of available nutrients during crop growth period due to increased level of fertilizers along with organics significantly increased the growth and yield components of finger millet, which in turn increased the grain and straw yield (Rani Perumal et al., 1991, Goudar, 2014 and Senthilkumar et al., 2018).

In conclusion the results from the study inferred that transplanting of 30 days old seedlings at closer spacing of 30x10 cm and application of FYM @ 10 tons $\mathrm{ha}^{-1}+125 \%$ RDF along with or without wooden log treatment resulted in the higher CGR, RGR and yield of finger millet and NAR increase with spacing under Krishna Agro-climatic conditions of Andhra Pradesh.

\section{References}

Anitha, D. 2015. Finger millet [Eleusine coracana (1.) Gaertn] productivity as influenced by crop geometry and age of seedlings. M.Sc. Thesis. Acharya N.G. Ranga Agricultural University, Hyderabad.

Borkar, L.S., Khawale, V.S., Raut, P.B., Patil, T.S 
and Kolte, H.S. 2008. Studies on spacing and nitrogen management under system of rice intensification (SRI). Journal of Soils and Crops. 18 (2): 438-441.

Goudar, P.K. 2014. Effect of rotation, use of organic and inorganic sources of nutrients on growth and yield of finger millet (Eleusine coracana L.). M.Sc. Thesis. University of Agricultural Sciences, GKVK, Bangalore.

Kalaraju, K., Deva Kumar, N., Nagaraja, N and Ningappa, K.B. 2011. Effect of methods of planting on growth and yield of finger millet genotypes under organic farming. Research on Crops. 10 (1): 20-24.

Mohabbesi A., Abbasian A., Bakhshipour, S and Hashem, A. 2011. Effect of different level of nitrogen and plant spacing on yield, yield components and physiological indices in high yield rice. American Eurasian Journal of Agriculture \& Environment Science. 10 (5): 893-900.

Nayak, B.C., Dalei, B.B and Choudhury, B.K. 2003. Response of hybrid rice (Oryza sativa) to date of planting, spacing and seedling rate during wet season. Indian Journal of Agronomy. 48 (3): 172-174.

Oghalo, S.O. 2011. Effect of population density on the performance of upland rice (Oryza sativa) in a forest-Savanna transition zone. International Journal of sustainable Agriculture. 3 (2): 44-48.

Rajesh, K. 2011. System of crop intensification in finger millet (Eleusine coracana (L.) Gaertn.) under irrigated condition. M.Sc Thesis. Tamil Nadu Agricultural University. Coimbatore.

Rajput, A. 2013. Effect of planting geometries on growth and yield of improved rice varities under depth of planting in system of rice intensification. Ph.D Thesis. Jawaharlal Nehru Krishi Vishwa Vidyalaya, Jabalpur. M.P.

Rajput, A., Rajput, S.S and Jha, G. 2017.
Physiological parameters leaf area index, crop growth rate, relative growth rate and net assimilation rate of different varieties of rice grown under different planting geometries and depths in SRI. International Journal of Pure and Applied Biosciences. 5 (1): 362-367.

Rani Perumal., Francis, H., Duraisamy, P., Kandaswamy, $\mathrm{P}$ and Palaniappan, S.P. 1991. Integrated nutrient management in Tamil Nadu. Technical Bulletin of Department of Soil Science and Agricultural Chemistry. T.N.A.U., Coimbatore, Tamil Nadu.

Senthilkumar, N., Poonkodi, P and Prabhu, N. 2018. Response of pearl millet to integrated use of organics and fertilizers. Journal of Ecobiotechnology. 10: 01-04.

Singh., Singh, M. K., Sachin Tyagi and Singh, S.S. 2018. Effect of integrated nutrient management on growth and yield of rice (Oryza sativa L.). International Journal of Current Microbiology and Applied Sciences. 7: 3671-3681.

Sridhara, C.J., Ramachandrappa, B.K., Kumarswamy, A.S and Gurumurthy, K.T. 2011. Effect of genotypes, planting geometry and methods of establishment on root traits and yield of aerobic rice. Karnataka Journal of Agriculture Science. 24 (2): 129-132.

Tilahun, T.F., Nigussie, D.R., Wondimu, B and Setegn, G. 2013. Effect of farmyard manure and inorganic fertilizers on the growth, yield and moisture stress tolerance of rainfed lowland rice. American Journal of Research Communication. 1 (4): 275-301.

Varghese, P.T., Sadanandan, N and Nair, R.V. 1976. A study on leaf area index and net assimilation rate of sunflower variety Peredovik as affected by graded doses of nitrogen and phosphorous. Agricultural Research Journal of Kerala. 14 (1): 53-57.

\section{How to cite this article:}

Aliveni, A. and Venkateswarlu, B. 2020. Physiological and Yield Response of Finger Millet Grown under Different Crop Geometries and Nutrient Management Practices. Int.J.Curr.Microbiol.App.Sci. 9(12): 532-537. doi: https://doi.org/10.20546/ijcmas.2020.912.063 